\title{
Modeling Teachers' Influence on Learners' Self-Directed Use of Technology for Language Learning Outside the Classroom
}

\begin{abstract}
Teachers are important social agents who shape the quantity and quality of students' selfdirected use of technology for learning outside the classroom. This study aimed to model the influence of teacher behaviors on learners' self-directed technology use. A conceptual model of three types of teacher support (affection support, capacity support and behavior support) that were reported to influence students' self-directed technology use for learning outside the classroom was generated based on interviews with 15 undergraduate foreign language learners. One hundred and sixty undergraduate foreign language learners were then surveyed to test the conceptual model. The path analysis of the survey data suggested that affection support influenced learner self-directed technology use through strengthened perceived usefulness, and that capacity support and behavior support influenced learner self-directed technology use through enhanced facilitating conditions and computer self-efficacy. The research findings highlight the importance of raising teachers' awareness of the different roles they can play and of enhancing their abilities to perform a combination of the roles to promote learner self-directed use of technology for learning outside the classroom.
\end{abstract}

Keywords: teacher technology use; self-directed learning with technology; informal learning; foreign language learning; post-secondary education

\section{Introduction}

Teachers play a significant role in shaping the quality of students' intellectual and social experiences (Davis, 2003). The instructional, affective and social relationships that teachers develop with students influence students' cognitive, affective and social learning behaviors (Davis, 2003; Farmer, Lines \& Hamm, 2011). Teachers exert their influence both explicitly through their instructional practices and implicitly through role modeling (Katyal \& Evers, 2004). Moreover, these influences manifest themselves directly in students' intellectual and social engagement at school and indirectly in students' learning beliefs and approaches to learning (Davis, 2003). Thus, a discussion of learners' autonomous learning behaviors outside the classroom must include an examination of teachers' roles.

The development of learner autonomy is a social process mediated by more capable others (Hardwin \& Oshige, 2011; Little, 2004), and teachers are important social agents who mediate students' autonomous learning behaviors outside the classroom. Teachers' beliefs and teaching behaviors may intentionally and/or unintentionally influence learners' autonomous learning both inside and outside the classroom (Lamb, 2008). Modeling the factors that affected university students' self-directed use of technology for learning, Author and colleagues (2012) found that teachers' and peers' encouragement and support were significant factors in predicting students' adoption of technology for learning outside the classroom. Research evidence has suggested that teachers' encouragement and support shape both the quantity and the quality of students' autonomous use of technology for learning outside the classroom (Author \& Colleagues, 2012; Margaryan \& Littlejohn, 2008). Furthermore, the factors influencing students' 
autonomous use of technology range from teachers' expectancies and instructional practices (Selwyn, 2008) to teachers' encouragement and guidance concerning the use of possible technology-enhanced materials for learning (Author \& Colleague, 2011; Author \& Colleagues, 2014; Castellano, Mynard, \& Rubesch, 2011; Deepwell \& Malik, 2008). Given the close connections between teacher behaviors and student autonomous learning behaviors, it is critical that teachers are aware of and capitalize on the various visible and invisible routes through which they can influence students' self-directed use of technology for learning beyond the classroom. Unfortunately, research studies have found that teachers tend to perceive themselves as having a limited responsibility for students' autonomous learning outside the classroom and are unaware of the potential roles they could play in promoting and supporting such behaviors (Chan, 2003; Thanh Van, 2011; Toffoli \& Sockett, 2013). Thus, it is important to identify clearly the various roles that teachers can play and the effects thereof so that teachers may be prepared better to exert their influence in fostering self-directed, autonomous users of technology for learning. This study aimed to enhance our understanding of this issue by identifying and modeling teachers' influence on students' self-directed use of technology for learning outside the classroom.

\section{Literature Review}

To understand teachers' roles in facilitating learners' self-directed use of technology for language learning, it is necessary first and foremost to understand what self-directed learning entails. Knowles (1975) defined self-directed learning as "a process in which individuals take the initiative, with or without the help from others, in diagnosing their learning needs, formulating goals, identifying human and material resources, choosing and implementing appropriate learning strategies and evaluating learning outcomes” (p. 18). Current research has approached self-directed learning from three perspectives: personal attribute, process and context (Brockett \& Hiemstra, 1991; Candy, 1991; Garrison, 1997). The personal attribute perspective emphasizes learners' propensity, willingness and capacity to use various resources and strategies to assume emotional and intellectual responsibilities in learning. The process perspective highlights the process through which learners manage their own learning, including planning, monitoring and evaluating learning. The context perspective stipulates that contexts influence the level of self-direction given to and perceived by learners, and affect the personal attribute and process aspect of self-direction (Song \& Hill, 2007). In the context of self-directed use of technology for language learning outside the classroom, helping learners to perceive the necessity and importance of technological resources for language learning and enabling them to access and make effective use of these resources for language learning are essential in enabling students to exert the self-directed learning personal attribute and process (Author, 2013). Thus, the roles teachers can play in facilitating learners' self-directed use of technology for language learning may need to center around supporting learners' self-initiated use of technological resources and venues to manage their self-directed learning process.

\subsection{Supports Student Need in Self-Directed Technology Use for Learning}

This thesis is supported by the literature on self-directed technology use from the learner perspective. Focusing on learners' views of self-directed learning in general, researchers have found that learners perceive teachers to be playing multiple roles in 
facilitating their self-directed learning, including assisting them in managing the learning process, advising them on learning strategies, creating a class structure and atmosphere that encourages and supports autonomous learning, and recommending resources and encouraging active use of these resources (Fang \& Zhang, 2012; Xu \& Xu, 2004). Wang (2007) found that, among the various roles of teachers, learners rated teachers' roles in providing resources and learning strategies, and motivating and teaching students how to engage in self-directed learning as more important than teachers' roles in assisting students in the planning, monitoring and evaluation of the self-directed learning process. Focusing specifically on self-directed learning outside the classroom, researchers have found that students report lacking confidence in their abilities to engage in out-of-class learning activities either due to a lack of information on possible learning resources and opportunities or because of the lack of ability to use resources effectively (Gamble et al., 2012; McKinney et al., 2004). This finding has been corroborated in research studies on students' use of technology outside the classroom, which found that students lacked a sophisticated understanding of the educational potentials of technological resources, of the variety of technological resources they could utilize and of how to use technological resources effectively for learning (Alajmi, 2011; Clark, Logan, Luckin, Mee \& Oliver, 2009; Kennedy \& Miceli, 2010; Oxford, 2009; Winke \& Goertler, 2008). Thus, from the learner's perspective, the support that teachers can provide in promoting self-directed use of technology for learning outside the classroom needs to focus on sharing technological resources, encouraging students to make active use of technological resources and helping learners to develop the capacity to use the resources effectively to engage in selfdirected learning.

\subsection{Teacher Impact on Student Self-directed Technology Use for Learning}

Teachers can provide this support through using technological resources during class instruction and engaging students in activities that involve the use of these technological resources. Fagerlund (2012) found that when teachers incorporated in-class technological activities that could be continued at home, such as watching videos and listening to songs, students' learning beyond the classroom improved. In fact, researchers have found that students use the technological resources that their teachers have used in class for self-directed learning purposes outside the classroom (Author, 2014; Author \& Colleague, 2011). Author and Colleague (2011) found that technologies used by the teachers in class were more likely to be adopted by students. Their in-class technology experience helped some students to transform their use of the technologies that they frequently used in their daily life, such as blogs, from entertainment tools to learning tools. Furthermore, students' perceptions of expectations or lack thereof concerning the use technology for learning and of assessment regimes influence whether they will make the effort to use it on their own or not (Selwyn, 2008).

Teachers can also provide support through encouraging and guiding students on how to use technological resources for learning. Carson and Mynard (2012) identified the various ways teachers could facilitate students' self-directed learning outside the classroom: 1) by providing students with conceptual information that raises their awareness of the language learning process and metalinguistic and metacognitive concepts; 2) by providing students with methodological information about resources and strategies and engaging them in experimenting and discovering what works for them and what does not; and 3) by providing students with psychological support for affective 
management. Research studies have found that advice from teachers on what technology to use for learning and how to use it has often been reported to drive students' out-ofclass language learning and influence the types of activities they engage in beyond the classroom (Deepwell \& Malik, 2008; Fagerlund, 2012; Inozu, Sahinkarakas \& Yumru, 2010). Ideas and support from teachers and peers in using technology to support learning have been found to be critical factors in affecting students' self-directed use of technology for learning (Author, 2013). Students have often been found to incorporate learning resources/activities recommended and shared by teachers into their learning ecology (Author, 2014; Author \& Colleagues, 2014; Gray et al., 2010). Furthermore, pedagogical or metacognitive guidance from teachers on how to use technological resources for learning are critical in helping learners to make the transition from using the technologies as entertainment tools to using them as learning tools (Johnson et al., 2009; McLoughlin \& Lee, 2010). It has been found that teachers' guidance on how to use different out-of-class learning activities shapes how learners utilize technological resources for learning (Author \& Colleagues, 2014).

Thus, current studies have identified various teacher behaviors that may influence learners' self-directed use of technology for learning outside the classroom. However, how do different types of teacher behaviors affect self-directed use of technology for learning outside the classroom? This study aimed to answer this research question by modeling teachers' influence on a group of foreign language learners' self-directed technology use outside the classroom. The current literature contains insufficient information to enable the construction of a conceptual model of the mediating factors and the pathways through which teacher behaviors influence learners' self-directed use of technology for learning. Therefore, in this study, a group of foreign language learners were interviewed on their views of how various teacher behaviors affected their selfdirected use of technology for language learning outside the classroom, and a conceptual model was generated based on the interview findings. The conceptual model was then tested through a survey of a larger sample of foreign language learners.

\section{Research Methods}

This research study consisted of two phases. The first phase involved individual semi-structured interviews to elicit students' views on the teacher behaviors that influenced their self-directed use of technology for language learning outside the classroom, and how these teacher behaviors influenced their out-of-class technology use. The interviews helped to identify the potential mediating factors and pathways of the effects of various teacher behaviors on learners' self-directed use of technology for learning. The second phase involved an online survey on student use of technology outside the classroom, and the teacher behaviors and mediating factors that were reported by the interviewees to affect their technology use. Path analysis was conducted on the

survey data to reveal how various teacher behaviors affected students' self-directed use of technology for language learning outside the classroom.

\subsection{Participants}

Participants were undergraduate students at a large comprehensive research university in Hong Kong who were taking second language courses at the time of the study. The study was announced through course coordinators of foreign language 
departments. Of the participants, 15 volunteered to participate in the interviews and 164 volunteered to take part in the online survey. After discarding incomplete questionnaires, 160 valid questionnaires were retained.

Interview participants included eight female and seven male students. They were studying a wide variety of languages, and most of them were studying the language as a major or minor and had been studying the language for more than one year.

Participants of the online survey ranged from 18 to 23 years old, with an average age of 20 ( $(\mathrm{SD}=1.48)$. Of the participants, $124(77 \%)$ were females, and $36(23 \%)$ were males. More than half of the participants were sophomores (57\%), 32\% were freshmen and $11 \%$ were juniors (the university adopted a 3-year undergraduate academic system). All but 8 of the participants were of Chinese ethnic background, 18\% were from the STEM (Science, Technology, Engineering and Mathematics) fields, and $82 \%$ were from non-STEM fields. The participants were studying a variety of languages including French (37\%), German (17\%), Spanish (15\%), Japanese (9\%), Korean (21\%) and English (1\%). Most of the participants were within the first two years of studying the language (within 1 year: $44 \%$; $1-2$ years: $43 \%$, and more than 2 years: $13 \%$ ). The majority of them rated themselves as beginners or absolute beginners of the target language (74\%), $24 \%$ rated themselves as of intermediate level, and only $2 \%$ declared themselves as of advanced level.

\section{Phase One of the Research Study}

\subsection{Data Collection and Data Analysis}

Phase one involved an interview study with the 15 participants. The interview questions were semi-structured with open-ended questions. During the interviews, the participants were asked to reflect on the technological resources they used outside the classroom for learning the target language, their teachers' attitudes to and use of technology in class, and the teacher behaviors that had influenced or would influence their use of technological resources outside the classroom and how. Interview questions were piloted and revised accordingly. The interviews were conducted in either English or Chinese, depending on the interviewees' preference, and each interview lasted around forty minutes. The participants were given minimal guidance in their responses, with only follow-up questions being asked to elicit more in-depth responses, and with clarification questions being asked to confirm the intended meaning by the participants.

The interview data were analyzed thematically to identify the teacher behaviors that were reported to influence students' self-directed use of technology for learning outside the classroom and the factors that mediated the influence of teacher behaviors on their self-directed technology use. The interview data were transcribed word-for-word in either English or Chinese, and the interview data were listened again to double-check the transcripts for accuracy. The interview data were first coded according to the teacher behaviors that were reported to influence students' self-directed use of technology for learning, and these teacher behaviors formed the organizational themes. With each organizational theme, the segments related to a particular teacher behavior were coded according to how the behavior affected learners' self-directed technology use. Similar codes were aggregated into analytic categories, which indicated the factors that mediated the effect of particular teaching behaviors. For instance, under the organizational theme, "effects of teacher recommending technological resources", the codes "what the teachers 
have introduced should be quite useful"; "I believe that what she recommends is suitable for us to do further practice"; "when the teacher introduces something, I would think it's quite useful and would go and check these out" were categorized into the analytic code "enhanced perceived usefulness of the resources". Thus, for the teaching behavior, "teacher recommendation of resources”, one mediating factor was “perceived usefulness”.

\subsection{Findings}

The participants reported five types of teacher behaviors that had influenced their use of technology outside the language class for learning: (1) encouraging students to use technological resources on their own outside the class for language learning, (2) recommending specific technological resources that students could utilize for learning outside the class, (3) guiding students on how to use technological resources for language learning, (4) using technologies in class, and (5) assigning technology-enhanced homework (see Table 1). Of the five behaviors, the effect of teacher recommendations was agreed on by all the participants, whereas the effect of assignments that involved the use of technological resources was supported by only three participants.

[Insert Table 1 Here]

\subsubsection{Impact of teacher behaviors on student self-directed technology use}

4.2.1.1. Impact of teacher encouragement: Affection support

The participants reported that teacher encouragement influenced their selfdirected use of technology for learning mainly through enhancing their awareness of the potential of some technological resources for language learning and reinforcing their perceived usefulness of these resources. Constant reminders from teachers to use technological resources for learning pushed some participants to check out these resources outside the class, which made them realize their usefulness. For instance, one participant commented: "He often reminded us to listen to radio stations. I tried it and found it quite useful". Another concurred that teacher encouragement pushed her to search out relevant resources: "The French teacher always encouraged us to listen to French more, so I tried to find some French videos in YouTube. I feel quite interested in these videos". In the case of another participant, teacher encouragement strengthened her perceived usefulness of the resources and led her to use the resources more frequently: "Because of their encouragement, I did it [read online Japanese websites] more frequently”. Teacher encouragement also made some participants realize the language learning potential of some technologies they frequently used for entertainment. For instance, one participant commented, "When the teacher constantly encouraged me, I'd approach the resources with greater consciousness of learning. In the past, I listened to songs totally for fun and quit it whenever I lost interest. Now I'd treat it more seriously". 4.2.1.2. Impact of teacher resource recommendation and tips: Capacity support

The participants reported that teachers' recommendation of resources and guidance on how to use the resources for language learning affected their self-directed use of technology for learning through both strengthening their perceived usefulness of the resources and enhancing their access to, and knowledge of how to use, the resources more effectively for language learning. For one thing, the participants reported that their teachers' recommendations introduced them to a new approach to learning and made them believe in the usefulness of the technological resources for learning. For instance, one participant said, "The teacher recommended a social networking site to us, which 
made me realize that it could be used for language study"; and another commented, "When the teacher recommended some websites to me, I'd go and check these sites out because I believed what the teachers introduced to us should be quite useful for learning French". For another thing, the participants felt that teachers' recommendations provided easy access to resources, as reflected in the following interview responses: "When teachers introduce some websites to me, I know where to find the learning resources"; "It [teachers' recommendation] saves me a lot of trouble. I don't need to go through a large volume of websites to search for the useful ones. In the past, I would simply quit it if I couldn't find any useful resources after spending a lot of time”. Also students tended to perceive these resources as more trustworthy: "Now I know where to search and what websites are of higher quality"; and "When the teacher recommended some online resources, we'd think the source is good and would try to use it even if we didn't know how to use it". The enhanced access to quality resources made the participants feel more confident in using the resources for learning: "If the resource was recommended by the teacher, it would be more trustworthy, and I would be more confident to use it... I believe that what she recommends is suitable for us to practice further". At the same time, the participants felt that the recommendations needed to be supported by teacher guidance on how to use the resources: "If the teacher just recommended a website to us, I usually wouldn't check it out. But if he showed us what the benefits of the website are and how to use the website, I would feel it was more useful". The participants further commented that when teachers guided them on how to use certain resources for language learning, they would approach the online resources with greater language awareness. For instance, one participant commented,

After the teacher reminded us of the formality/informality of the Japanese used in some movies and TV shows, I paid more attention to the language when I watched movies and consciously compared the language used in the movies with the language we learned in class. I'd bring the language I picked up in the movies to class to check with the teacher.

\subsubsection{Impact of teacher in-class technology use: Behavior support}

The participants reported that teacher use of technological resources in classes also influenced their self-directed use of technology for language learning through enhancing their capacity to use, and boosting their confidence in using, the resources for learning. The participants felt that in-class use of technology provided them with useful resources for learning (e.g., "when the teacher used the website, I would get the hint that this website is a good resource, and I'd follow up with the resource after the class"), offered clues on how to use the resources (e.g., "I'd know how to use the resources and I'd follow his way of using the resources for learning”), and boosted their confidence in being able to use the resources (e.g., "After listening to these songs and watching the lyrics, we found that we could understand some of them. We would be more confident. So we'd go back to search for the singer's other songs that the teacher didn't play in class”). Furthermore, the participants reported that teachers assigning homework involving the use of technological resources influenced their self-directed use of technology by giving them access to resources (e.g., "we can get familiar with the technologies and form a habit of using them") and enhancing their understanding of these resources (e.g., “we will know what these resources can be used for”). 
In all, the interview data revealed three categories of teacher support in the model: affection support, involving teachers' encouragement of and justification for using technological resources, which enabled and strengthened students' perception of the usefulness of technological resources; capacity support, involving teachers' recommendation of technological resources and guidance on how to use the resources, which enhanced students' abilities to locate and use technological resources for learning; and behavior support, involving teachers engaging students in learning activities enhanced by technologies inside and outside the classroom and providing information about the resources, demonstrating the use of particular resources and scaffolding students in experimenting with the resources. The interview data also suggested that perceived usefulness (i.e., the belief in enhanced learning through using technological resources) mediated the effects of affection support and capacity support, while facilitating conditions (i.e., perceived availability of relevant knowledge, resources and support that facilitate the use of technological resources for learning) and computer selfefficacy (i.e., perceived confidence in using the technological resources for learning) mediated the effects of capacity support and behavior support.

4.2.2. A conceptual model of teacher impact on student self-directed technology use

Based on the interview findings and the current literature, a conceptual model of teacher influence on learner self-directed use of technology for language learning outside the classroom was generated. The model posited that: (1) affection support affected selfdirected technology use indirectly through perceived usefulness; (2) capacity support affected self-directed technology use indirectly through facilitating conditions, which affected self-directed use of technology directly and indirectly via computer self-efficacy and perceived usefulness (Author, 2013; Author \& Colleagues, 2012; El-Gayar \& Moran, 2006; Teo, 2009; Yousafzai et al., 2007). Computer self-efficacy affected self-directed technology use directly and indirectly via perceived usefulness (Author \& Colleagues, 2012; Chang \&Tung, 2008; Hsu, Wang \& Chiu, 2009; Rahimi \& Katal, 2012). Capacity support also affected self-directed technology use indirectly through perceived usefulness; and (3) behavior support affected self-directed technology use indirectly through facilitating conditions, which affected self-directed use of technology directly and indirectly via computer self-efficacy and via perceived usefulness.

[Insert Figure 1 Here]

\section{Phase Two of the Research Study}

\subsection{Data Collection and Data Analysis}

Phase two involved the survey study. The survey collected data on the frequency of students' use of technology for language learning outside the language classroom, and the teacher behaviors and mediating factors as revealed in the interview findings (See Appendix 1 for information on each construct and its indicating items). The dependent variable, technology use, assessed the frequency of technology use to support various needs in language learning. A 6-point Likert scale was used, with 1 indicating never, 2 indicating less than 1 hour a week, 3 indicating 1-3 hours, 4 indicating 4-7 hours, 5 indicating 7-14 hours, and 6 indicating more than 14 hours. To ensure that this construct reflected self-directed use of technology for learning, an item that measured the frequency of teacher-required technology use to finish language class assignments was included at the beginning of this section, and excluded from the analysis of self-directed 
technology use. The independent constructs included the three categories of teacher support and the three factors that mediated the effects of teacher behaviors-perceived usefulness, facilitating conditions and computer self-efficacy-as reported in the interviews. All the independent constructs were rated on a 6-point Likert-type scale, with 1 indicating strongly disagree and 6 indicating strongly agree. In addition, some demographic characteristics of the students (gender, age, major, the target language being studied, years of studying the language and language proficiency level) were collected. The survey items were constructed with reference to previous works on language learners' self-regulated use of technology for learning and to the literature on technology adoption (Author, 2013; Venkatesh, 2000). Prior to answering the survey, students were given the definition of technology used in this study: various types of digital technological tools, sites or resources including the Internet, online communities, online games, online audio/video, online chatting tools, blogs, Webchat, WhatsApp, social networking sites like Facebook and Twitter, multimedia software, mobile devices like mobile phone, IPad, MP3 players.

Path analysis was used to analyze how various types of teacher support interacted with the mediating predictor variables to influence the participants' use of technology outside the language classroom. This analytic technique was also used to test the fit of hypothesized models to the data, unravel the intricate relationships between the factors in the model, and identify the factors that mediated the potential influence of teacher behavior on learner technology use. Amos 20.0 was used to estimate the models, and Maximum Likelihood Estimation was used to fit the model and estimate parameters. The absolute fit indices, $\chi 2$ statistic and CMIN/DF, the parsimonious indices, root mean square of approximation (RMSEA), the incremental fit indices, the comparative fit index (CFI) and the Tucker-Lewis index (TLI), were used to assess the model fit. The absolute indices measure whether the variables are independent, the parsimonious index indicates the badness-of-fit of the model (larger values signal worse fit), and the incremental fit indices measure the goodness-of-fit of the model (larger values signal good fit) (Tabachnick \& Fidell, 2013).

\subsection{Findings}

The participants were found to hold positive perceptions of the usefulness of technological resources for language learning $(\mathrm{M}=4.47, \mathrm{SD}=0.57)$ and were quite confident about their abilities to use technology for language learning $(M=4.49$, $\mathrm{SD}=0.73)$. They spent an average of 1-3 hours each week using technology on their own for language learning purposes outside their language classroom. They rated teacher support for technology use slightly above 4 , giving affection support the highest rating $(\mathrm{M}=4.13, \mathrm{SD}=0.95)$ and capacity support the lowest rating with the largest variation $(\mathrm{M}=4.02, \mathrm{SD}=1.00)$ (See Appendix 1). The three types of teacher support were highly correlated with each other.

\subsubsection{Model fitting}

[Insert Table 2 Here]

The model fit indices for the conceptual model were satisfactory: chi-square was 9.36 and CMIN/DF was 1.04, $\mathrm{p}=.41$. RMSEA was 0.02 (lower $90 \%=0.00$; higher $90 \%=$ 0.09). CFI was 1.00 and TLI was 1.00. All the fit indices indicated that the model fit the data well. However, two paths were not statistically significant: the direct effect of 
capacity support on perceived usefulness was negative and not significant ( $\beta=-0.05$, $\mathrm{p}=.67$ ), and the direct effect of facilitating conditions on perceived usefulness was not significant $(\beta=0.09, \mathrm{p}=.36)$. The conceptual model was modified by the deletion of the two non-significant pathways, and the final model had a chi-square value of 10.38 , CMIN/DF value of 0.94 ( $\mathrm{p}=.50)$, RMSEA value of .00 (.00, .08), CFI value of 1.00 and TLI value of 1.00, which all indicated a good fit to the data (see Figure 2 for the final model). The whole model explained $22 \%$ of the variation in learners' self-directed use of technology for language learning outside the classroom.

[Insert Table 3 Here]

[Insert Figure 2 Here]

\subsubsection{The final model}

5.2.2.1. Affection support influenced self-directed use through perceived usefulness

Table 4 shows that affection support influenced self-directed use of technology indirectly through perceived usefulness $(\beta=0.08, \mathrm{p}<.01)$. The greater the efforts teachers made to justify the value of technology for language learning and to encourage students to utilize these resources, the stronger students perceived the usefulness of these resources for language learning $(\beta=0.27, p<.001)$, which increased the frequency of their self-directed use of technology for learning outside the classroom $(\beta=0.33, p<.001)$. This finding on the positive significant effects of affection support for learners' self-directed use of technology for learning confirmed the findings from other research studies (Deepwell \& Malik, 2008; Fagerlund, 2012; Inozu, Sahinkarakas \& Yumru, 2010).

[Insert Table 4 Here]

\subsubsection{Capacity support and behavior support influenced self-directed use through facilitating conditions and computer self-efficacy}

Concurring with the current research literature (Author, 2014; Author \& Colleagues, 2014; Fagerlund, 2012; Gray et al., 2010), capacity support and behavior support were also found to have a significant positive effect on self-directed use of technology $(\beta=0.03, p<.01$ and $\beta=0.05, p<.01$ respectively). However, their indirect effects were mediated by facilitating conditions, computer self-efficacy and perceived usefulness. The more support teachers provided in enhancing students' capacity to use technology for learning - such as recommending technological resources and providing tips on how to use the resources for language learning - the greater the students perceived the availability of knowledge, resources and help in using these resources for language learning $(\beta=0.20, p<.05)$. Similarly, teachers engaging students in using technological resources for language learning both inside and outside the classroom enhanced the likelihood of students perceiving the existence of favorable conditions (i.e., the availability of relevant knowledge, resources and support, for self-directed technology use $[\beta=0.29, p<.01])$. The more favorable the students perceived the conditions, the more confident they were in their ability to use technology for language learning $(\beta=0.64$, $\mathrm{p}<.001$ ), which directly affected the likelihood of their using technology on their own for language learning outside the language class $(\beta=0.24, \mathrm{p}<.01)$ and indirectly affected technology use via perceived usefulness $(\beta=0.09, \mathrm{p}<.01)$.

Contrary to our hypothesis, capacity support (i.e., teachers recommending resources and offering tips on how to use the resources) was found to have an insignificant negative effect on perceived usefulness. This could partly be explained by the high correlation between affection support and capacity support $(\mathrm{r}=0.80, \mathrm{p}<.001)$. 
Teachers recommending and discussing how to use certain technological resources could potentially deliver a two-fold message: (1) these were useful resources that could facilitate language learning; and (2) this was where students could find quality resources and how they could use them to improve a certain aspect of language. The message about the usefulness of the resources overlapped with that of affection support, whereas the message in terms of the sources and tips was the unique contribution of capacity support for learner self-directed use of technology for learning. This might be the reason why the hypothesized path from capacity support to perceived usefulness was found not to be significant. Furthermore, this group of participants were already spending an average of 1-3 hours each week engaged in self-directed use of technology for language learning $(M=2.79)$ and had positive perceptions of the usefulness of technology for language learning $(\mathrm{M}=4.47)$. For them, capacity support might have influenced them more in terms of providing information on where to locate quality resources. This explanation was reflected in some participants' interview responses. As one participant said, “Before the teacher recommended the resources, I didn't know where to find the resources. The idea was not new to me at all. But when the teacher introduced some websites to me, I then knew where to locate such resources”.

\section{Discussion}

Previous studies on teacher technology adoption have focused primarily on how to help teachers to integrate technologies into class instruction, and have found that despite enhanced computer access and technology training, teachers are still quite limited in integrating instructional technologies as meaningful pedagogical tools to facilitate student learning due to a number of internal and external factors (Buabeng_Andoh, 2012; Ertmer \& Ottenbreit-Leftwich, 2010). Researchers have put forward various suggestions for teacher technology education, such as facilitating changes in teachers' attitudes to technology integration and pedagogical beliefs (Ertmer et al., 2012) and creating a positive culture through teacher-led communities of practices (Kopcha, 2010). However, given that the potential of technology for learning goes far beyond what is happening in the classroom, and that students are already utilizing technologies outside the classroom for learning but with limited sophistication (Alajmi, 2011; Benson, 2006; Clark, Logan, Luckin, Mee \& Oliver, 2009; Greenhow, Robelia, \& Hughes, 2009; Kennedy \& Miceli, 2010), it is essential that we not only focus on what teachers could do with technologies inside the classroom but also explore how teachers could help maximize the potentials of technology for learning by enhancing the quantity and quality of learner self-directed use of technology for learning outside the classroom. This study found that teachers influenced learners' self-directed use of technology for language learning outside the language classroom through affection support such as encouragement, capacity support such as resource recommendations and metacognitive tips, and behavior support such as encouraging students to use technological resources inside and outside the classroom. Teachers' use of technology in the classroom can affect student technology behavior outside the classroom, but is just one of the influential factors. Teachers could also influence student technology behavior outside the classroom through various other means such as encouragement, resource recommendations, homework involving the use of technological resources and guidance on how to use technological resources for learning. Unfortunately, teachers have been found to be largely unaware of their responsibilities 
and influence on students' autonomous learning outside the language classroom (Chan, 2003; Toffoli \& Sockett, 2013). Thus, it is important for professional development programs to stress teachers' responsibilities for, as well as the various ways they could influence, students' self-initiated technology use outside the classroom.

This study further found that these different types of teacher support influenced learners' out-of-class self-directed use of technology for language learning in different ways: affection support predicted self-directed technology use through strengthened perceptions of the usefulness of technological resources for language learning, whereas capacity support and behavior support predicted self-directed technology use through enhanced perceptions of facilitating conditions and self-efficacy in using technological resources for language learning. Thus, different types of teacher support have different functions. Simply encouraging students to use technological resources for language learning is not sufficient to promote their self-directed use of technology for learning. Teachers may also need to recommend useful resources and teach students how to select quality resources, and how to use these resources effectively for language learning. This advisory role is critical but does not come to teachers naturally (Mynard \& Carson, 2012). If we agree that the educational potential of technologies extends far beyond in-class instruction, the technological pedagogical content knowledge that teachers need to be equipped with entails much more than knowledge of, and skills in using, technologies to create and facilitate meaningful student learning experience inside the classroom. Teachers also need to be equipped with the knowledge and skills necessary to advise students on selecting and using technological resources effectively to meet their individual learning needs, to design pedagogical activities that bridge students' in-class and out-of-class learning experience in a way that promotes students' willingness and capacities for out-of-class use of technology for learning, and to provide scaffolding mechanisms that promote and support learners' self-directed use of technology for learning outside the classroom(Carson \& Mynard, 2012; Kop \& Fournier, 2011; Reinders, 2010). This new set of teacher knowledge and skills need to be highlighted in professional development initiatives that aim to maximize the potentials of technology for education. This professional development focus calls for a series of research studies that could yield a deeper understanding of the nature of this new set of knowledge and skills and the approaches to foster this new set of knowledge and skills so as to support related professional development initiatives.

This study focused on the effects of a few teacher behaviors that students reported to influence directly their self-directed technology use outside the classroom. It did not examine the potential effects of other relevant teacher behaviors such as teachers' instructional practices and support for students' self-regulated learning, teachers' instructional practices for bridging in-class and out-of-class learning, teachers' explicit expectations concerning the use of technologies in course syllabus and assessment, and so on. Future research studies are needed to examine the potential of other teacher behaviors and support in promoting learners' self-directed technology use. This study adopted a survey methodology to generate a model of the influence of a few teacher behaviors on learner's self-directed technology use. However, to gain a better understanding of this issue, more in-depth studies are needed to examine the specific features of different teacher behaviors that are necessary to influence self-directed technology use. For instance, it is important to delve deeper into the differential effects of 
different approaches to encouragement and recommendation (e.g., the connections of the encouragement and recommendation with the curriculum, the encouragement and recommendation as an integrated component of instruction vs. the encouragement and recommendation as a stand-alone training component) and different frequencies of encouragement and recommendation, to examine the different types of technology use in class (e.g., technology used in a peripheral manner vs. technology used as the core pedagogical tool), and to examine the different dimensions of advice on technology use and how to provide this advice. Furthermore, this study examined the influence of teachers on the quantity of self-directed technology use for learning. Further studies are needed to examine teacher influence on the quality of self-directed technology use for learning, that is, what and how different teacher behaviors affect the ways students utilize different technological resources for learning outside the classroom.

\section{Conclusion}

This study examined the effects of a few teacher behaviors on students' selfdirected use of technology for language learning outside the classroom. Teacher behaviors that provide affection, capacity and behavior support were found to predict self-directed technology use, and these different types of teacher support exerted their influence in different ways. Affection support influenced self-directed technology use through strengthened perceived usefulness. Capacity support and behavior support influenced self-directed technology use in similar ways, both predicting self-directed technology use through enhanced facilitating conditions and computer self-efficacy. The research findings highlight the importance of raising teachers' awareness of the substantial support they need to provide to students to enhance their self-directed use of technology for learning outside the classroom. The study also calls for greater research attention and efforts in understanding the nature of teachers' influence on learner selfdirected technology use and in exploring effective ways in which teachers could exert their influence to foster learners' out-of-class self-directed use of technology for learning more effectively.

This study has a few limitations. First, the study focused on the subject matter of foreign language learning. The key teacher factors that affect students' self-directed use of technology for learning outside the classroom and the relative importance and influence of each factor might differ across different subject matters. In different subject matters, depending on the accessibility of the technological resources and the ease of use of the resources, capacity support might matter more or less than other types of support in predicting self-directed use of technology for learning. Second, this study was based on survey responses from a group of undergraduate foreign language learners in Hong Kong. The particularities of the participants might have biased the research findings. In cultures where teachers are respected less as authoritarian figures, teachers' encouragement and recommendations may not play as significant a role as they do in cultures that are heavily influenced by Confucian educational philosophy and norms, as is the case in Hong Kong. In these cultures, teachers' behavior support might matter more. The relative importance and influence of these teacher behaviors might also show a different pattern in K-12 contexts, where learners have a greater reliance on teachers, are still developing their self-regulated learning skills and are facing greater exam pressures. Furthermore, the ways in which teacher behaviors are influential might vary in contexts where learners 
show different profiles of perceived usefulness of, and computer self-efficacy in, technologies for learning.

\section{References}

Alajmi, M. (2011). Web 2.0 technologies adoption in Kuwait. Unpublished Doctoral dissertation. University of North Texas, Texas.

Author \& Colleagues (2014)

Author \& Colleagues (2012)

Author \& Colleague (2011)

Author (2014)

Author (2013)

Benson, P. (2006). Autonomy in language teaching and learning. Language Teaching, 40, 21-40.

Buabeng-Andoh, C. (2012). Factors influencing teachers' adoption and integration of information and communication technology into teaching: A review of the literature. International Journal of Education and Development Using Information and Communication Technology, 8, 136-155.

Brockett, R. G., \& Hiemstra, R. (1991). Self-direction in adult learning: Perspectives on theory, research, and practice. New York: Routledge.

Candy, P. C. (1991). Self-direction for Lifelong Learning. San Francisco: Jossey-Bass.

Carson, L. \& Mynard, J. (2012) Introduction. In J. Mynard \& L. Carson (Eds.), Advising in Language Learning: Dialogue, Tools and Context (pp. 3-25). Harlow, UK: Pearson Education Limited.

Castellano, J., Mynard, J., \& Rubesch, T. (2011). Student technology use in a self-access center. Language Learning \& Technology, 15(3), 12-27.

Chan, V. (2003). Autonomous language learning: The teachers' perspectives. Teaching in Higher Education, 8, 33-54.

Chang, S. \& Tung, F. (2008). An empirical investigation of students’ behavioral intentions to use the online learning course websites. British Journal of Educational Technology, 39(1), 71-83.

Clark, W., Logan, K., Luckin, R., Mee, A., \& Oliver, M. (2009). Beyond WLLA 2.0: Mapping the technology landscapes of young learners. Journal of Computer Assisted Learning, 25, 56-69.

Davis, H. A. (2003). Conceptualizing the role and influence of student-teacher relationships on children's social and cognitive development. Educational Psychologist, 38, 207-234.

Deepwell, F., \& Malik, S. (2008). On campus, but out of class: an investigation into students' experiences of learning technologies in their self-directed study. ALT-J, Research in Learning Technology, 16(1), 5-14.

El-Gayar, O. F. \& Moran, M. (2006). College students' acceptance of tablet PCs: An application of hte UTAUT model. Annual Meeting of the Decision Sciences Institute Conference Proceedings, 2845-2850.

Ertmer, P. A., Ottenbreit-Leftwich, A. T., Sadik, O., Sendurur, E. \& Sendurur, P. (2012). Teacher beliefs and technology integration practices: A critical relationship. Computers \& Education, 59, 423-435.

Ertmer, P. A., \& Ottenbreit-Leftwich, A. T. (2010). Teacher technology change: how 
knowledge, beliefs, and culture intersect. Journal of Research on Technology in Education, 42, 255-284.

Fagerlund, T. (2012). Learning and using English and Swedish beyond the classroom: activity systems of six upper secondary school students. Unpublished master's thesis. University of Jyväskylä, Finland.

Fang, F. M. \& Zhang, L. (2012). Teachers’ roles in promoting students’ learner autonomy in China. English Language teaching, 5, 51-56.

Farmer, T. W., Lines, M. M. \& Hamm, J. V. (2011). Revealing the invisible hand: The role of teachers in children's peer experiences. Journal of Applied Developmental Psychology, 32, 247-256.

Gamble, C., Aliponga, J., Wilkins, M., Koshiyama, Y., Yoshida, K., \& Ando, S. (2012). Examining Learner Autonomy Dimensions: Students’ Perceptions of Their Responsibility and Ability. In A. Stewart \& N. Sonda (Eds.), JALT2011 Conference Proceedings (pp. 263-272). Tokyo: JALT.

Garrison, D. R. (1997). Self-directed learning: Toward a comprehensive model. Adult Education Quarterly, 48, 18-33.

Greenhow, C., Robelia, E., \& Hughes, J. (2009). WLLA 2.0 and classroom research: What path should we take now? Educational Researchers, 38(4), 246-259.

Hardwin, A. \& Oshige, M. (2011). Self-regulation, coregulation, and socially shared regulation: Exploring perspectives of social in self-regulated learning theory. Teachers College Record, 113, 240-264.

Inozu, J., Sahinkarakas, S., \& Yumru, H. (2010). The nature of language learning experiences beyond the classroom and its learning outcomes. US-China Foreign Language, 8, 14-21.

Johnson, L., Levine, A., \& Smith, R. (2009). The 2009 Horizon Report. Austin, Texas: The New Media Consortium.

Katyal, K. R. \& Evers, C. (2004). Teacher leadership and autonomous student learning: Adjusting to the new realities. International Journal of Educational Research, 41, 367-382.

Kennedy, C. \& Miceli, T. (2010). Corpus-assisted creative writing: Introducing intermediate Italian learners to a corpus as a reference resource. Language Learning and Technology, 14(1), 28-44.

Knowles, M. S. (1989). The Making of an Adult Educator. San Francisco: Jossey-Bass.

Kop, R., \& Fournier, H. (2011). New dimensions to self-directed learning in an open networked learning environment. International Journal of Self-Directed Learning, 7(2), 2-20.

Kopcha, T. J. (2010). A systems-based approach to technology integration using mentoring an communities of practice. Education Technology Research Development, 58, 175-190.

Lamb, T. (2008). Learner autonomy and teacher autonomy: Synthesising an agenda. In T. Lamb \& H. Reinders (Eds.), Learner and Teacher Autonomy: Concepts, Realities, and Responses (pp. 269-284). Amsterdam, Netherland: John Benjamins Publishing Company

Little, D. (2004). Constructing a theory of learner autonomy: Some steps along the way. In K. Mäkinen, P. Kaikkonen, \& V. Kohonen (Eds.), Future Perspectives in Foreign Language Education (pp. 15-25). Oulu. 
Margaryan, A., \& Littlejohn, A. (2008). Repositories and communities at cross-purposes: Issues in sharing and reuse of digital learning resources. Journal of Computer Assisted Learning, 24(4), 333-347.

McKinney, K., Vacca, K., Medvedeva, M. A. \& Malak, J. (2004). Beyond the classroom: An exploratory study of out-of-class learning in sociology. Teaching Sociology, 32, 43-60

McLoughlin, C. \& Lee, M. L. (2010). Personalized and self regulated learning in the Web 2.0 era: International exemplars of innovative pedagogy using social software. Australian Journal of Educational Technology, 26(1), 28-43.

Mynard, J. \& Carson, L. (2012), Advising in Language Learning: Dialogue, Tools and Context. Harlow, UK: Pearson Education Limited.

Oxford, R. (2009). The influence of technology on second language writing. In R. Oxford \& J. Oxford (Eds.), Second language teaching and learning in the Net generation (pp. 9-21). Manoa, HI: National Foreign Language Resource Center.

Rahimi, M., \& Katal, M. (2012). The role of metacognitive listening strategies awareness and podcast-use readiness in using podcasting for learning English as a foreign language. Computers in Human Behavior, 28(4), 1153-1161.

Reinders, H. (2010). Towards a classroom pedagogy for learner autonomy: A framework of independent language learning skills. Australian Journal of Teacher Education, 35, 40-55.

Selwyn, N. (2008). An investigation of differences in undergraduates' academic use of the internet. Active Learning in Higher Education, 9, 11-22.

Song, L. Y. \& Hill, J. R. (2007). A conceptual model for understanding self-directed learning in online environments. Journal of Interactive Online Learning, 6, 27-42.

Tabachnick, B. G., \& Fidell, L. S. (2013). Using multivariate statistics, $6^{\text {th }}$ ed. Boston, MA: Allyn and Bacon.

Teo, T. (2009). The impact of subjective norm and facilitating conditions on pre-service teachers' attitude toward computer use: A structural equation modeling of an extended technology acceptance model. Journal of Educational Computing Research, 40(1), 89-109

Thanh, Van, N. (2011). Language learners' and teachers' perceptions relating to learner autonomy-Are they ready for autonomous language learning? VNU Journal of Science, Foreign Languages, 27, 41-52.

Toffoli, D. \& Sockett, G. (2013). University teachers’ perceptions of online informal learning of English (OILE). Computer Assisted Language Learning. DOI: 10.1080/09588221.2013.776970

Hsu, M. K., Wang, S. W. \& Chiu, K. K. (2009). Computer attitude, statistics anxiety and self-efficacy on statistical software adoption behavior: An empirical study of online MBA learners. Computers in Human Behavior, 25, 412-420.

Venkatesh, V. (2000). Determinants of perceived ease of use: Integrating control, intrinsic motivation, and emotion into the technology acceptance model. Information Systems Research, 11, 342-365.

Winke, P. \& Goertler, S. (2008). Did we forget someone? Students' computer access and literacy for CALL. CALICO Journal, 25(3), 482-509.

$\mathrm{Xu}$, J. F., \& Xu. L. (2004). Exploring College English teachers' roles in the autonomous learning mode. Higher Education Research, 3, 77-79. 
Wang, Y. (2007). What do autonomous language learners expect their teachers to do?-A study on teacher's roles in autonomous learning project. Foreign Language World, 4, 005.

Yousafzai, S. Y., Foxall, G. R. \& Pallister, J. G. (2007). Technology acceptance: A metaanalysis of the TAM: Part 1. Journal of Modeling in Management, 2(3), 251-280. 
Appendix 1 The Survey Constructs and Items and Descriptive Statistics (N=160)

\begin{tabular}{|c|c|c|c|c|c|c|c|}
\hline Construct & \# of item & Survey Questions & $\mathrm{a}$ & Min. & Max. & Mean & SD \\
\hline \multirow[t]{2}{*}{$\begin{array}{l}\text { Affection } \\
\text { Support }\end{array}$} & \multirow[t]{2}{*}{2} & $\begin{array}{l}\text { My language teacher encourages us to use technology for } \\
\text { language learning outside the classroom }\end{array}$ & \multirow[t]{2}{*}{0.77} & \multirow[t]{2}{*}{1.00} & \multirow[t]{2}{*}{6.00} & \multirow[t]{2}{*}{4.13} & \multirow[t]{2}{*}{0.95} \\
\hline & & $\begin{array}{l}\text { My language teacher discusses with us how technological } \\
\text { resources or tools could enhance language learning }\end{array}$ & & & & & \\
\hline \multirow[t]{2}{*}{$\begin{array}{l}\text { Capacity } \\
\text { Support }\end{array}$} & \multirow[t]{2}{*}{2} & $\begin{array}{l}\text { My language teacher shares with us useful technological } \\
\text { resources/sites/tools for language learning outside the } \\
\text { classroom }\end{array}$ & \multirow[t]{2}{*}{0.88} & \multirow[t]{2}{*}{1.00} & \multirow[t]{2}{*}{6.00} & \multirow[t]{2}{*}{4.02} & \multirow[t]{2}{*}{1.00} \\
\hline & & $\begin{array}{l}\text { My language teacher shares tips/strategies on how to use } \\
\text { technological resources or tools for language learning }\end{array}$ & & & & & \\
\hline \multirow[t]{3}{*}{$\begin{array}{l}\text { Behavior } \\
\text { Support }\end{array}$} & \multirow[t]{3}{*}{3} & $\begin{array}{l}\text { My language teacher often uses technological resources or tools } \\
\text { in her/his classes }\end{array}$ & \multirow[t]{3}{*}{0.78} & \multirow[t]{3}{*}{1.00} & \multirow[t]{3}{*}{5.67} & \multirow[t]{3}{*}{4.09} & \multirow[t]{3}{*}{0.95} \\
\hline & & $\begin{array}{l}\text { My language teacher engages us with learning activities that } \\
\text { involve the use of technological resources or tools }\end{array}$ & & & & & \\
\hline & & $\begin{array}{l}\text { My language teacher assigns class assignments that are based } \\
\text { on technological resources }\end{array}$ & & & & & \\
\hline \multirow[t]{6}{*}{ Tech Use } & \multirow[t]{6}{*}{8} & To learn more about the language and culture & \multirow[t]{6}{*}{0.91} & \multirow[t]{6}{*}{1.13} & \multirow[t]{6}{*}{5.88} & \multirow[t]{6}{*}{2.79} & \multirow[t]{6}{*}{0.83} \\
\hline & & To help persist in achieving language learning goals & & & & & \\
\hline & & $\begin{array}{l}\text { To help monitor language learning progress (assess learning } \\
\text { progress, adjust learning goals and plan learning tasks or } \\
\text { materials) }\end{array}$ & & & & & \\
\hline & & To seek learning strategies and tips & & & & & \\
\hline & & To expand opportunities to use the language & & & & & \\
\hline & & $\begin{array}{l}\text { To sustain/enhance motivation and interest in learning the } \\
\text { language }\end{array}$ & & & & & \\
\hline
\end{tabular}




\begin{tabular}{|c|c|c|c|c|c|c|c|}
\hline & & To seek engaging learning activity or experience & & & & & \\
\hline & & $\begin{array}{l}\text { To connect with native speakers and/or other learners of the } \\
\text { language }\end{array}$ & & & & & \\
\hline \multirow{7}{*}{$\begin{array}{l}\text { Perceived } \\
\text { Usefulness }\end{array}$} & \multirow[t]{7}{*}{7} & Enhances my language learning outcomes & \multirow[t]{7}{*}{0.77} & \multirow[t]{7}{*}{2.86} & \multirow[t]{7}{*}{6.00} & \multirow[t]{7}{*}{4.47} & \multirow[t]{7}{*}{0.57} \\
\hline & & Improves my language learning experience and environment & & & & & \\
\hline & & Helps monitor my language learning progress & & & & & \\
\hline & & $\begin{array}{l}\text { Sustains or enhances my motivation and interest in learning the } \\
\text { language }\end{array}$ & & & & & \\
\hline & & Expands venues of emotional support and learning support & & & & & \\
\hline & & Expands my learning resources and venues & & & & & \\
\hline & & Expands language use opportunities & & & & & \\
\hline \multirow[t]{3}{*}{$\begin{array}{l}\text { Computer } \\
\text { Self } \\
\text { Efficacy }\end{array}$} & \multirow[t]{3}{*}{3} & $\begin{array}{l}\text { I am confident with my abilities in using technologies } \\
\text { effectively for language learning }\end{array}$ & \multirow[t]{3}{*}{0.91} & \multirow[t]{3}{*}{2.00} & \multirow[t]{3}{*}{6.00} & \multirow[t]{3}{*}{4.49} & \multirow[t]{3}{*}{0.73} \\
\hline & & $\begin{array}{l}\text { I am confident with my abilities in selecting appropriate } \\
\text { technologies for my language learning needs }\end{array}$ & & & & & \\
\hline & & $\begin{array}{l}\text { I am confident with my abilities in using technologies to create } \\
\text { enjoyable language learning experience }\end{array}$ & & & & & \\
\hline \multirow[t]{3}{*}{$\begin{array}{l}\text { Facilitation } \\
\text { Conditions }\end{array}$} & \multirow[t]{3}{*}{3} & $\begin{array}{l}\text { I have the resources necessary to use technologies for language } \\
\text { learning }\end{array}$ & \multirow[t]{3}{*}{0.83} & \multirow[t]{3}{*}{1.00} & \multirow[t]{3}{*}{6.00} & \multirow[t]{3}{*}{4.31} & \multirow[t]{3}{*}{0.84} \\
\hline & & $\begin{array}{l}\text { I have the knowledge necessary to use technologies for } \\
\text { language learning }\end{array}$ & & & & & \\
\hline & & $\begin{array}{l}\text { When I need help on using technology to enhance language } \\
\text { learning, someone is there to help me }\end{array}$ & & & & & \\
\hline
\end{tabular}


Table 1. Learner Reported Influential Teacher Behaviors and Mediating Predictive Factors

\begin{tabular}{|c|c|c|}
\hline $\begin{array}{l}\text { Categories of } \\
\text { Teacher Support }\end{array}$ & Teacher Behavior & $\begin{array}{l}\text { Factors that Mediated the Effect } \\
\text { of Teacher Behavior on Self- } \\
\text { directed Technology Use }\end{array}$ \\
\hline Affection Support & Teacher encouragement (9) & Perceived usefulness (9) \\
\hline \multirow[t]{2}{*}{ Capacity Support } & Teacher recommendation (15) & $\begin{array}{l}\text { Knowledge of where to access } \\
\text { quality resources (10) } \\
\text { Perceived usefulness (7) }\end{array}$ \\
\hline & Teacher guidance on use (7) & $\begin{array}{l}\text { Knowledge of how to use the } \\
\text { resources (6) } \\
\text { Perceived usefulness (1) }\end{array}$ \\
\hline \multirow[t]{2}{*}{ Behavior Support } & $\begin{array}{l}\text { Teacher technology use in class } \\
\text { (10) }\end{array}$ & $\begin{array}{l}\text { Knowledge of where to access } \\
\text { quality resources (5) } \\
\text { Knowledge of how to use the } \\
\text { resources (4) } \\
\text { Perceived usefulness (3) }\end{array}$ \\
\hline & Technology assignment (3) & $\begin{array}{l}\text { Knowledge of where to access } \\
\text { quality resources (3) }\end{array}$ \\
\hline
\end{tabular}

Note: (\#) stands for the number of interviewees who expressed the opinion 
Table 2. Correlations of the Variables Included in the Model

\begin{tabular}{llllllll}
\hline & $\begin{array}{l}\text { Technology } \\
\text { Use }\end{array}$ & $\begin{array}{l}\text { Affection } \\
\text { Support }\end{array}$ & $\begin{array}{l}\text { Capacity } \\
\text { Support }\end{array}$ & $\begin{array}{l}\text { Behavior } \\
\text { Support }\end{array}$ & $\begin{array}{l}\text { Perceived } \\
\text { Usefulness }\end{array}$ & $\begin{array}{l}\text { Facilitating } \\
\text { Conditions }\end{array}$ & $\begin{array}{l}\text { Computer } \\
\text { Self-efficacy }\end{array}$ \\
\hline Technology use & 1 & & & & & & \\
Affection Support & $0.26^{* *}$ & 1 & & & & \\
Capacity Support & $0.27^{* *}$ & $0.80^{* *}$ & 1 & & & \\
Behavior Support & $0.27^{* *}$ & $0.61^{* *}$ & $0.61^{* *}$ & 1 & & \\
$\begin{array}{l}\text { Perceived Usefulness } \\
\text { Facilitating }\end{array}$ & $0.42^{* *}$ & $0.35^{* *}$ & $0.28^{* *}$ & $0.22^{* *}$ & 1 & \\
$\begin{array}{l}\text { Conditions } \\
\begin{array}{l}\text { Computer Self- } \\
\text { efficacy }\end{array}\end{array}$ & $0.34^{* *}$ & $0.37^{* *}$ & $0.38^{* *}$ & $0.41^{* *}$ & $0.30^{* *}$ & 1 & \\
\hline
\end{tabular}


Table 3. Fit Indices for Two Different Path Models

\begin{tabular}{llllll}
\hline Model & Chi-square & CMIN/DF & RMSEA & TLI & CFI \\
\hline $\begin{array}{l}\text { Guideline (Tabachnick } \\
\text { \& Fidell, 2013) }\end{array}$ & Non-significant & $<2$ & $<0.05$ & $>0.95$ & $>0.95$ \\
\hline Conceptual Model & $9.36(\mathrm{p}=0.41)$ & 1.04 & $\begin{array}{l}.02 \\
(.00, .09)\end{array}$ & 1.00 & 1.00 \\
& & & $\begin{array}{l}.00 \\
(.00, .08)\end{array}$ & 1.00 & 1.00 \\
\hline Final Model & $10.38(\mathrm{p}=0.50)$ & 0.94 & & & \\
\hline
\end{tabular}


Table 4. Standardized Direct-, Indirect-, and Total-Effects of the Final Model

\begin{tabular}{|c|c|c|c|c|c|}
\hline \multirow[t]{2}{*}{ Outcome } & \multirow[t]{2}{*}{ Determinant } & \multirow[t]{2}{*}{ Mediator } & \multicolumn{3}{|c|}{ Standardized Estimates } \\
\hline & & & $\begin{array}{l}\text { Direct } \\
\text { Effect }\end{array}$ & $\begin{array}{l}\text { Indirect } \\
\text { Effect }\end{array}$ & $\begin{array}{l}\text { Total } \\
\text { Effect }\end{array}$ \\
\hline \multirow{6}{*}{$\begin{array}{l}\text { Technology } \\
\text { Use } \\
\left(R^{2}=.22\right)\end{array}$} & Affection Support & $\begin{array}{l}\text { Perceived } \\
\text { Usefulness }\end{array}$ & & $.08 * *(.03)$ & $.08 * *$ \\
\hline & Capacity Support & $\begin{array}{l}\text { Facilitating } \\
\text { Conditions }\end{array}$ & & $.03 * *(.02)$ & $.03 * *$ \\
\hline & Behavior Support & $\begin{array}{l}\text { Facilitating } \\
\text { Conditions }\end{array}$ & & $.05 * *(.02)$ & $.05 * *$ \\
\hline & $\begin{array}{l}\text { Perceived } \\
\text { Usefulness }\end{array}$ & & $.33^{* * *}(.11)$ & & $.33^{* * *}$ \\
\hline & $\begin{array}{l}\text { Facilitating } \\
\text { Conditions }\end{array}$ & $\begin{array}{l}\text { Computer Self- } \\
\text { Efficacy }\end{array}$ & & $.20 *(.05)$ & $.20 *$ \\
\hline & $\begin{array}{l}\text { Computer } \\
\text { Self-Efficacy }\end{array}$ & $\begin{array}{l}\text { Perceived } \\
\text { Usefulness }\end{array}$ & $.24 * * *(.08)$ & $.09 * *(.03)$ & $.33^{* * *}$ \\
\hline
\end{tabular}

Note: ${ }^{* * *} p<.001 ;{ }^{* *} p<.01 ;{ }^{*} p<.05$. The first number reports the effect size; the number in the parentheses is the standard error. 


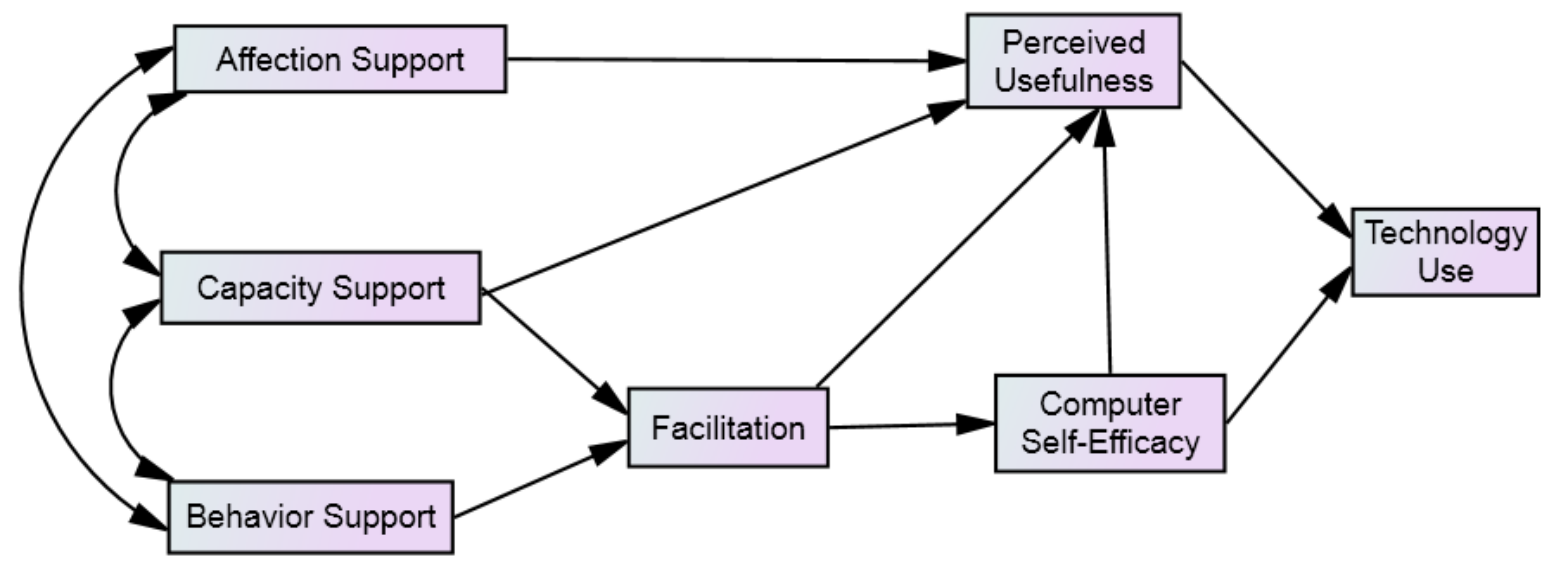

Figure 1. The Conceptual Model

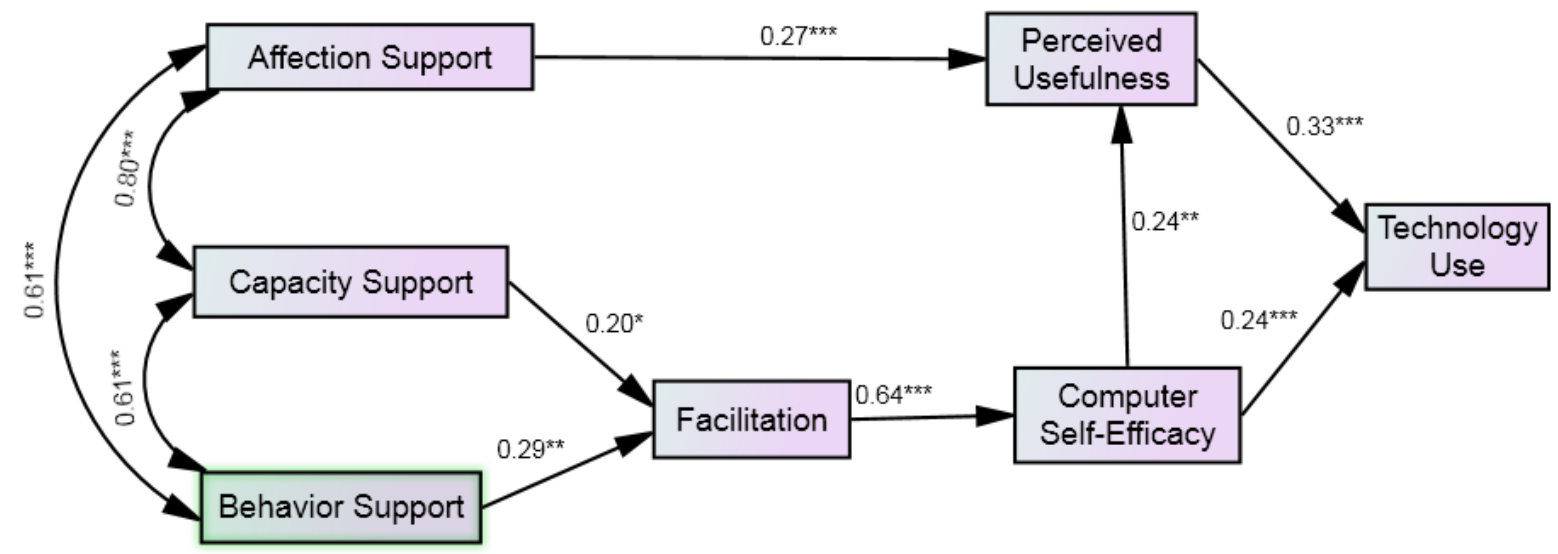

Figure 2. The Final Model 